\title{
A Novel Phylogroup of Pseudomonas cichorii Identified Following an Unusual Disease Outbreak on Tomato
}

\author{
Sujan Timilsina, Heather Adkison, Anna L. Testen, Eric A. Newberry, Sally A. Miller, Matthews L. Paret, \\ Gerald V. Minsavage, Erica M. Goss, Jeffrey B. Jones, and Gary E. Vallad ${ }^{\dagger}$
}

First, fourth, seventh, eighth, and ninth authors: Department of Plant Pathology, University of Florida, Gainesville 32611; first, second, and tenth authors: Gulf Coast Research and Education Center, University of Florida, Balm 33598; third and fifth authors: Department of Plant Pathology, The Ohio State University, Ohio Agricultural Research and Development Center, Wooster 44691; fourth and sixth authors: North Florida Research and Education Center, Quincy 32251; and eighth author: Emerging Pathogens Institute, University of Florida, Gainesville 32610.

Accepted for publication 13 June 2017.

\begin{abstract}
Recently, in Central Florida tomato production fields, tomato foliage and fruit were observed with symptoms similar to bacterial speck. Fluorescent pseudomonads were consistently isolated and the strains were characterized by standard LOPAT tests, pathogenicity tests, and genetic characterization using $16 \mathrm{~S}$ ribosomal RNA (rRNA) sequences and multilocus sequence analysis (MLSA) of conserved housekeeping genes. LOPAT test results indicated that the strains were likely Pseudomonas cichorii. These strains were pathogenic on tomato and were also pathogenic on lettuce, the host for the type strain of $P$. cichorii. Likewise, strains of $P$. cichorii isolated in Florida since the early 1980s from hosts

other than tomato, along with the type strain, were also pathogenic on tomato. Genetic characterization using 16S rRNA and MLSA confirmed that the strains were most closely related to $P$. cichorii but varied significantly from the type strain. The Florida $P$. cichorii strains formed a separate phylogenetic group along with $P$. cichorii strains isolated from tomato in Tanzania. These strains were different from the previously described morphotypes and genomovars of $P$. cichorii. Our results indicate the presence of a genetically distinct group of multihost pathogenic $P$. cichorii strains that have been present in Florida since at least the early 1980s.
\end{abstract}

Tomato is a major crop in Florida, with an ideal subtropical climate that allows for nearly yearlong production from north to south Florida. Although various pathogenic bacteria affect tomato production throughout the year, outbreaks caused by pathogenic Pseudomonas strains are typically favored by periods of extended rainfall and cool weather in Florida. Three diseases caused by different Pseudomonas spp. are reported from Florida: bacterial speck caused by Pseudomonas syringae pv. tomato, bacterial leaf blight caused by $P$. viridiflava (Jones et al. 1984), and pith necrosis caused by $P$. corrugata (Jones et al. 1983b). Foliar disease symptoms caused by bacterial speck consist of small, dark-brown, raised lesions with a yellow halo (LeBoeuf et al. 2005), whereas bacterial leaf blight symptoms consist of tissue necrosis (Jones et al. 1983b, 1984).

Tomato foliage and fruit exhibiting symptoms similar to bacterial speck were observed from 2011 and 2012. However, uncharacteristic of $P$. syringae pv. tomato or $P$. viridiflava, these symptoms occurred during periods of warm weather when day temperatures exceeded $29^{\circ} \mathrm{C}$. Foliar symptoms consisted of irregular lesions with distinct yellow margins (Fig. 1) and fruit exhibiting pinpoint sunken lesions, distinct from those symptoms caused by Xanthomonas perforans, the prevalent warm-weather pathogen associated with tomato in Florida (Vallad et al. 2009). Preliminary characterization identified the strains as $P$. cichorii, considered a warm-weather pathogen able to grow under high temperature and humidity (Jones et al. 1984), a novel pathogen on tomato in Florida.

†Corresponding author: G. E. Vallad; E-mail: gvallad@ufl.edu

*The $\boldsymbol{e}$-Xtra logo stands for "electronic extra" and indicates that one supplementary table and three supplementary figures are published online.

(c) 2017 The American Phytopathological Society
P. cichorii is reported to have a wide range (Stead et al. 2003) on hosts of high economic importance, including tomato, lettuce, and watermelon. $P$. cichorii was initially reported on endive (Swingle 1925) and later was recovered from rots on head lettuce in New York (Burkholder 1954). The bacterium is widely distributed, with recent reports from Belgium (Cottyn et al. 2009), Greece (Trantas et al. 2013) Italy (Scortichini et al. 2002), Turkey (Aysan et al. 2003), and Tanzania (Testen et al. 2015). The pathogen was previously isolated in Florida on chrysanthemum, celery, geranium, and hibiscus (Chase 1986; Engelhard et al. 1983; Jones et al. 1983a; Pohronezny et al. 1994) and, more recently, on Stevia rebudiana (Strayer et al. 2012) and Duranta erecta (Gumtow et al. 2013). Tomato was first reported as a host for P. cichorii in 1974 in New Zealand (Wilkie and Dye 1974). Symptoms associated with $P$. cichorii on tomato were described as being similar to late blight of tomato (Wilkie and Dye 1974) and pith-necrosis like symptoms (Testen et al. 2015). Along with tomato, plants from the Asteraceae family, including Lactuca sativa (lettuce), Cichorium endivia (endive) and Helianthus annus (sunflower), are regarded as common hosts of $P$. cichorii.

Based on phylogenetic analysis using gyrB and $r p o D, P$. cichorii is grouped within the $P$. syringae pathogen complex (Yamamoto et al. 2000) and, more recently, was placed in phylogroup 11 based on multilocus sequence analysis (MLSA) of housekeeping genes (Berge et al. 2014). A standard LOPAT assay that tests for levan production, oxidase and proteolytic activity, arginine dihydrolase utilization, and tobacco hypersensitivity is used to differentiate $P$. cichorii strains from other fluorescent pseudomonads (Lelliott et al. 1966). Within $P$. cichorii, three distinct morphotypes were defined based on colony formation and fluorescent pigmentation (Cottyn et al. 2009). Using BOX-polymerase chain reaction (PCR) and MLSA, a new genomovar of $P$. cichorii causing tomato pith necrosis was reported, indicating genetic variation among $P$. cichorii strains from diverse hosts (Trantas et al. 2013). 
The recent isolation of $P$. cichorii from tomato in Florida could be due to a recent introduction of tomato strains or, alternatively, new infection of tomato by endemic strains. The purpose of this study was to characterize the recently isolated $P$. cichorii strains from tomato in Florida using pathogenicity tests to determine host range, and conserved gene sequences to compare tomato strains with strains isolated from other hosts in Florida. In addition, we studied genetic diversity of $P$. cichorii strains isolated over a more than 30 -year period and from various hosts in Florida in order to clarify

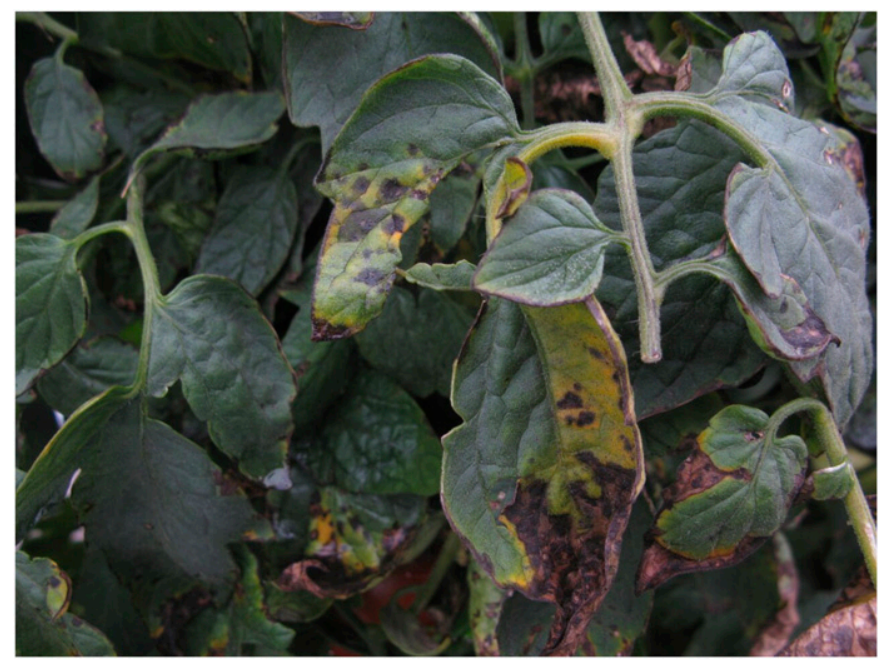

Fig. 1. Bacterial disease symptoms observed in tomato foliage caused by Pseudomonas cichorii. the genetic relationships with strains reported from other areas of the world.

\section{MATERIALS AND METHODS}

Bacterial strains and isolation. The bacterial strains used in this study included those recently isolated from tomato in Florida and strains isolated from various plant hosts in Florida since the early 1980s (Table 1). Based on the LOPAT tests, the tomato stains were most closely related to $P$. cichorii. Thus, the type strain of P. cichorii, $\mathrm{PC} 22^{\mathrm{T}}\left(=\right.$ ATCC $\left.10857^{\mathrm{T}}=\mathrm{CFBP} 2101^{\mathrm{T}}=\mathrm{LMG} 2162^{\mathrm{T}}\right)$ (Jones et al. 1990) and representative $P$. cichorii strains previously reported from different hosts in Florida were used in this study. The bacterial strains were plated on nutrient agar (Difco) and on King's B medium (KB) to detect fluorescence (King et al. 1954). In total, 18 strains isolated from tomato and 7 strains isolated from seven different hosts in Florida were also characterized in this study. In addition to strains isolated in Florida, $P$. cichorii strains recently reported from tomato in Tanzania, pumpkin in Tennessee, soybean in South Korea, and potato in Japan were also included for genetic comparisons.

Pathogenicity tests. For each strain, $50 \mathrm{ml}$ of bacterial suspensions prepared from 24-h cultures and adjusted to approximately $10^{8} \mathrm{CFU} / \mathrm{ml}$ were spray inoculated onto 6-week-old plants of susceptible 'Bonnie Best' tomato. The plants were sealed in plastic bags and maintained in a growth chamber at $28^{\circ} \mathrm{C}$ for $48 \mathrm{~h}$. Given that $P$. cichorii are common pathogens of lettuce (Burkholder 1954; Mirik et al. 2011), romaine lettuce plants were also spray inoculated in the same manner. At least two plants were inoculated for each strain and the experiment was repeated. Following the appearance of disease symptoms after $48 \mathrm{~h}$, bacteria were isolated

TABLE 1. List of Pseudomonas cichorii strains used for this study ${ }^{a}$

\begin{tabular}{|c|c|c|c|c|c|c|c|c|c|c|}
\hline Strain $^{b}$ & $\operatorname{Host}^{\mathrm{c}}$ & Year & Location & $16 \mathrm{~S}$ & gapl & gltA & gyrB & rpoD & $c t s$ & Source \\
\hline GEV417 & Tomato & 2011 & Florida & 2 & 2 & 2 & 2 & 2 & 2 & This study \\
\hline GEV1093 & Tomato & 2012 & Florida & 3 & 3 & 3 & 3 & 3 & NS & This study \\
\hline GEV1105 & Tomato & 2012 & Florida & NS & 3 & 3 & 3 & 3 & NS & This study \\
\hline GEV1112 & Tomato & 2012 & Florida & NS & 3 & 3 & 3 & 3 & NS & This study \\
\hline GEV1124 & Tomato & 2012 & Florida & NS & 3 & 3 & 3 & 3 & NS & This study \\
\hline GEV1127 & Tomato & 2012 & Florida & NS & 3 & 3 & 3 & 3 & NS & This study \\
\hline GEV1129 & Tomato & 2012 & Florida & NS & 3 & 3 & 3 & 3 & NS & This study \\
\hline GEV1141 & Tomato & 2012 & Florida & NS & 3 & 3 & 3 & 3 & NS & This study \\
\hline GEV1144 & Tomato & 2012 & Florida & NS & 3 & 3 & 3 & 3 & NS & This study \\
\hline GEV1149 & Tomato & 2012 & Florida & NS & 3 & 3 & 3 & 3 & NS & This study \\
\hline GEV1151 & Tomato & 2012 & Florida & NS & 3 & 3 & 3 & 3 & 3 & This study \\
\hline GEV1154 & Tomato & 2012 & Florida & NS & 3 & 3 & 3 & 3 & NS & This study \\
\hline GEV1158 & Tomato & 2012 & Florida & NS & 3 & 3 & 3 & 3 & NS & This study \\
\hline GEV1164 & Tomato & 2012 & Florida & NS & 3 & 3 & 3 & 3 & NS & This study \\
\hline GEV1169 & Tomato & 2012 & Florida & NS & 3 & 3 & 3 & 3 & NS & This study \\
\hline GEV1171 & Tomato & 2012 & Florida & NS & 3 & 3 & 3 & 3 & NS & This study \\
\hline GEV1173 & Tomato & 2012 & Florida & NS & 3 & 3 & 3 & 3 & NS & This study \\
\hline GEV1178 & Tomato & 2012 & Florida & 3 & 3 & 3 & 3 & 3 & NS & This study \\
\hline PC2 & Geranium & 1985 & Florida & 5 & 6 & 8 & 9 & 11 & 6 & This study \\
\hline PC4 & Chrys & 1984 & Florida & 3 & 5 & 5 & 5 & 5 & NS & This study \\
\hline $\mathrm{PC} 22^{\mathrm{T}}$ & Endive & 1929 & Germany & 1 & 1 & 1 & 1 & 1 & 1 & This study \\
\hline $\mathrm{PC} 24$ & Hibiscus & 1984 & Florida & 4 & 4 & 4 & 4 & 4 & NS & This study \\
\hline $\mathrm{PC} 25$ & Basil & 1986 & Florida & 2 & 2 & 3 & 7 & 9 & NS & This study \\
\hline PC27 & F. pan & 1985 & Florida & 2 & 5 & 6 & 6 & 6 & 4 & This study \\
\hline PC37 & F. lyr & 1985 & Florida & 2 & 5 & 7 & 8 & 8 & 5 & This study \\
\hline PC49 & $\mathrm{CT}$ & 1995 & Florida & 2 & 5 & 7 & 8 & 10 & NS & This study \\
\hline PPST 50936 & Stevia & 2012 & Florida & 4 & NS & NS & 7 & 7 & NS & Strayer et al. 2012 \\
\hline Pseudomonas sp. StFLB209 & Potato & NA & Japan & 6 & 6 & 9 & 10 & 12 & 6 & Morohoshi et al. 2014 \\
\hline P. cichorii JBC1 & Soybean & 2008 & South Korea & 1 & 1 & 1 & 1 & 1 & 1 & Ramkumar et al. 2015 \\
\hline P. cichorii $\mathrm{TN}-\mathrm{E} 4$ & Pumpkin & 2014 & Tennessee & 7 & NS & NS & 11 & 13 & NS & Newberry et al. 2016 \\
\hline P. cichorii 14-WTREC & Pumpkin & 2014 & Tennessee & 8 & NS & NS & 11 & 13 & NS & Newberry et al. 2016 \\
\hline Mab1A & Tomato & 2014 & Tanzania & 4 & 2 & 10 & 8 & 14 & NS & This study \\
\hline Msu3A & Tomato & 2014 & Tanzania & 9 & 7 & 11 & 12 & 15 & NS & This study \\
\hline
\end{tabular}

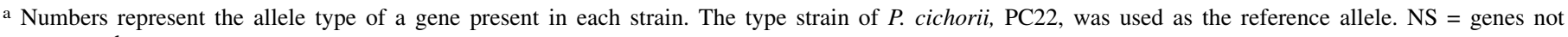
sequenced.

${ }^{b}$ Superscript ${ }^{\mathrm{T}}$ indicates type strain.

c Abbreviations: Chrys $=$ chrysanthemum, F. pan $=$ Ficus pandurate, F. lyr $=$ F. lyrata, and CT $=$ crown of thorns. 
from lesions on $\mathrm{KB}$ to confirm that the symptoms were associated with the strain used for inoculation.

PCR amplification and gene sequencing. Bacterial strains were grown overnight at $28^{\circ} \mathrm{C}$ on nutrient agar. The $16 \mathrm{~S}$ ribosomal RNA (rRNA) gene was sequenced for three representative strains isolated from tomato along with $P$. cichorii strains isolated from other hosts for comparison with the reference strains (Marchesi et al. 1998). Multiple copies of the 16S rRNA gene were detected in Florida tomato strains that resulted in sequencing errors. Therefore, the PCR products were cloned prior to sequencing, as described below. The PCR products from strains with multiple copies of $16 \mathrm{~S}$ rRNA gene were purified using a Qiagen PCR purification kit (Qiagen N.V.). Single copies for each of the amplified products were then cloned into Escherichia coli using the pGEM-T plasmid vector (Promega Corp/). Colonies of E. coli carrying a single copy of $16 \mathrm{~S}$ rRNA sequence from each individual $P$. cichorii strain were amplified using specific primers. Two clones for each strain were sequenced to obtain a consensus sequence.

Based on preliminary results from $16 \mathrm{~S}$ rRNA genes, four housekeeping genes-gapA, gyrB, gltA, and $r p o D$ - from all $P$. cichorii strains isolated in Florida were amplified (Hwang et al. 2005). The resulting PCR products were Sanger sequenced at the Interdisciplinary Center for Biotechnology Research at University of Florida. Along with $P$. cichorii isolated in Florida, four housekeeping genes from two $P$. cichorii strains recently reported from tomato in Tanzania were sequenced at the Ohio State University. Berge et al. (2014) defined Pseudomonas phylogroups based on cts gene sequences using a threshold of $4.0 \%$ for phylogroup and $1.8 \%$ for clade delineation. Representative $P$. cichorii strains from Florida were sequenced for the cts gene using primers described by Sarkar and Guttman (2004).

Phylogenetic analysis. The resulting sequences from individual strains were compared with sequences available from the National Center for Biotechnology Information (NCBI) and Plant Associated and Environmental Microbe Database (PAMDB) to find the closest relatives. Based on sequence similarity, sequences of closely related $P$. cichorii and $P$. syringae strains were retrieved from the databases for phylogenetic analyses. The sequences for respective genes were aligned individually using MUSCLE (Edgar 2004) in MEGA v. 6 software (Tamura et al. 2013). Sequences from the four housekeeping genes were concatenated to generate a combined phylogenetic tree. A maximum-likelihood phylogenetic tree was generated using the general time-reversible model with $\gamma$-distributed invariant sites within MEGA with 1,000 bootstrap
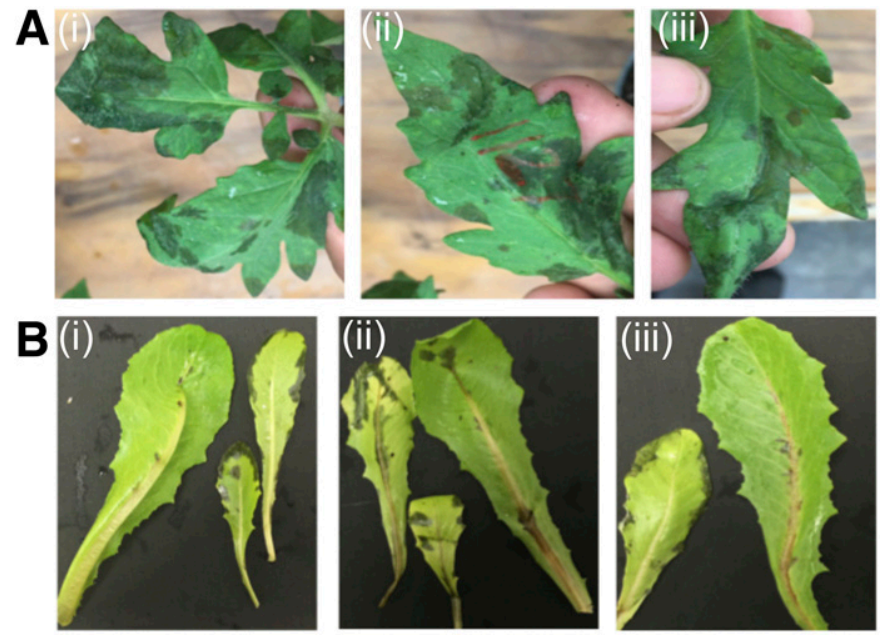

Fig. 2. Disease symptoms on tomato and lettuce hosts ( $48 \mathrm{~h}$ postinoculation) inoculated with representative Pseudomonas cichorii strains isolated from Florida along with the type strain on $\mathbf{A}$, tomato and $\mathbf{B}$, lettuce. Representative strains were (i) GEV417, (ii) GEV1127, and (iii) P. cichorii PC22. samples. Phylogenetic analyses of 16S rRNA and housekeeping gene sequences were carried out using the same model in MEGA.

Multiple MLSA schemes are available for characterizing Pseudomonas spp. Although different housekeeping genes are used for characterizing Pseudomonas spp. in various MLSA schemes (Hwang et al. 2005; Mulet et al. 2010; Trantas et al. 2013), gyrB and $r p o D$ genes are included in more than one MLSA scheme. In addition, Yamamoto et al. (2000) reported that significant phylogenetic information on Pseudomonas spp. can be retrieved using gyrB and $r p o D$ gene sequences. Thus, along with the MLSA using four housekeeping genes, Pseudomonas strains were phylogenetically analyzed using only the concatenated sequences of gyrB and $r p o D$ genes.

Pseudomonas phylogroups were determined by phylogenetic comparison of cts gene sequences for representative $P$. cichorii strains in Florida with sequences available from the Morris multilocus sequence typing scheme in PAMDB (Morris et al. 2010). The genetic distance between $P$. cichorii strains isolated from Florida to representatives of Pseudomonas phylogroups and clades was calculated using Kimura-2 parameter model, with $\gamma$ correction of 1 using MEGA.

GenBank accession numbers. Genes sequenced during this study were submitted to the NCBI database. The accession numbers for each gene sequenced during this study are gapl = KX673643 to KX673668, KY172992, and KY172993; gltA = KX673669 to KX673694, KY172994, and KY172995; gyrB = KX673695 to

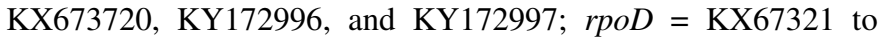
KX673746, KY172998, and KY172999; cts = KY940267 to KY940272; and 16S = KX670410 to KX670420.

\section{RESULTS}

Isolation and phenotypic characterization. Bacteria were isolated from symptomatic tissue, which was similar but not identical to symptoms observed for bacterial speck disease caused by $P$. syringae pv. tomato (Fig. 1). Unlike bacterial speck, the symptoms included irregular leaf lesions with distinct yellow margins along with fruit exhibiting sunken, pinpoint necrotic lesions. Interestingly, these symptoms were observed when temperatures in central Florida were in excess of $29^{\circ} \mathrm{C}$, unfavorable for the development of bacterial speck caused by $P$. syringae pv. tomato. All bacterial strains isolated from tomato were fluorescent on KB. The strains were negative for levan production, arginine dihydrolase activity, and pectolytic activity but positive for oxidase activity and caused a hypersensitive reaction when infiltrated into tobacco leaves. The LOPAT results indicated that the strains are P. cichorii.

Pathogenicity test. All Florida tomato strains were pathogenic on tomato and produced symptoms similar to natural infection (Fig. 2A). Furthermore, Florida strains isolated from tomato were also pathogenic on lettuce, producing disease symptoms $48 \mathrm{~h}$ postinoculation (Fig. 2B). Disease incidence was observed in $100 \%$ of the inoculated plants. Typical $P$. cichorii was reisolated from symptomatic tissue. Interestingly, the $P$. cichorii type strain $\mathrm{PC} 22^{\mathrm{T}}$ was also pathogenic on tomato. Among the other P. cichorii strains from Florida, PC2, PC24, PC25, PC37, PC49, and PPST 50936, isolated from geranium, hibiscus, basil, Ficus lyrata, crown of thorns, and stevia, respectively, were also pathogenic on tomato (Supplementary Fig. S1). However, PC4 and PC27 isolated from chrysanthemum and $F$. pandurata produced no obvious symptoms on tomato.

Genetic characterization. Results from MLSA and 16S rRNA sequences were in agreement with LOPAT characterization and confirmed the strains as $P$. cichorii. The Pseudomonas strains shared high sequence similarity with housekeeping genes (Fig. 3; Supplementary Fig. S2) and the 16S rRNA gene (Fig. 4) of the type strain P. cichorii $\mathrm{PC} 22^{\mathrm{T}}$. However, strains from Florida formed a distinct cluster even though they originated from multiple hosts. The $16 \mathrm{~S}$ and housekeeping gene sequences from the strains isolated from tomato 
were identical to each other, except GEV417. The tomato strain sequences varied from the type strain $P$. cichorii $\mathrm{PC} 22^{\mathrm{T}}$ in gapl, gltA, gyrB and $r p o D$ by a total of 106 of 2,043 nucleotides. Sequences from the unique tomato strain GEV417 differed by a total of 20 nucleotides from the other tomato strains. The $P$. cichorii strains isolated from hosts other than tomato were within the same phylogenetic group as the other $P$. cichorii strains from tomato (Fig. 3). The sequence types of genes for each strain used in this study are listed in Table 1. The nontomato strains from Florida carried multiple different allelic forms of housekeeping genes compared with tomato $P$. cichorii strains (Fig. $3)$. Only PC25 shared $100 \%$ sequence identity with tomato strains in gapl and gltA (Table 1). Strain PC25, isolated from basil, was distinct

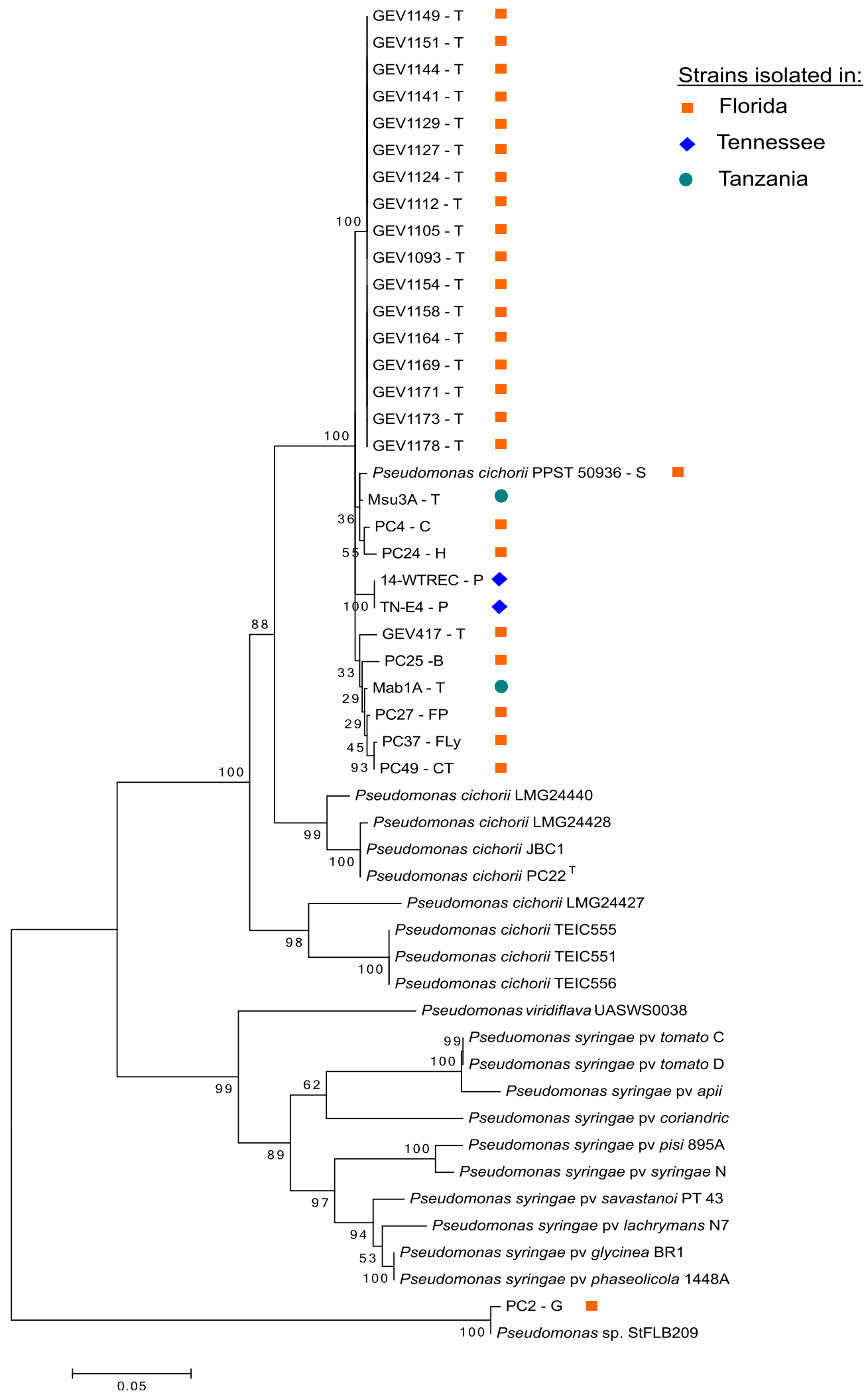

Fig. 3. Maximum-likelihood phylogeny of Pseudomonas strains isolated from Florida using concatenated sequences of gyrB and $r p o D$ genes. Hosts of isolation for strains isolated from Florida, Tennessee, and Tanzania are provided next to the strain name: $\mathrm{T}=$ tomato, $\mathrm{P}=$ pumpkin, $\mathrm{B}=$ basil, $\mathrm{FP}=$ Ficus pandurata, FLy $=$ F. lyrata, CT $=$ crown of thorns, $\mathrm{S}=$ stevia, $\mathrm{C}=$ chrysanthemum, $\mathrm{H}=$ hibiscus, and $\mathrm{G}=$ geranium. Bootstrap values for each branch are expressed as percentage and scale bar represents substitutions per site. 
based on rpoD sequences. Similarly, the geranium strain PC2, identified as $P$. cichorii by the LOPAT tests, had $16 \mathrm{~S}$ rRNA sequences similar to a Pseudomonas strain from Japan isolated from potato leaf (accession AB512620) (Fig. 4). The housekeeping genes also grouped PC2 with Pseudomonas strain StFLB209 (accession AP014637) isolated in Japan from a potato root (Someya et al. 2009).

Based on sequence analysis, the $P$. cichorii strains isolated from tomato in Tanzania were closely related to the Florida strains. The gapl gene of Mab1A was identical to GEV417 and PC25, and gyrB was identical with PC37 and PC49. Although not identical, Msu3A isolated in Tanzania had sequences similar to $P$. cichorii strains isolated in Florida.

Sequences of $g y r B$ and $r p o D$ genes from Florida $P$. cichorii strains were concatenated and phylogenetically compared with various Pseudomonas strains characterized using different MLSA schemes (Fig. 3). The P. cichorii strains from Florida formed a separate phylogenetic group compared with the three previously described morphotypes and genomovars of $P$. cichorii strains, including the type strain $\mathrm{PC} 22^{\mathrm{T}}$. Two $P$. cichorii strains isolated from pumpkin in Tennessee also clustered with the Florida $P$. cichorii strains along with the strains isolated from tomato in Tanzania.

Phylogenetic analysis of $16 \mathrm{~S}$ rRNA sequences produced results similar to those observed using the housekeeping genes (Fig. 4). Two representative tomato strains differed by 4 nucleotides in the $16 \mathrm{~S}$ gene from the $P$. cichorii type strain PC22T. Strain GEV417 showed a single nucleotide difference from the other Florida tomato strains. Florida strain PC4 isolated from chrysanthemum in 1984

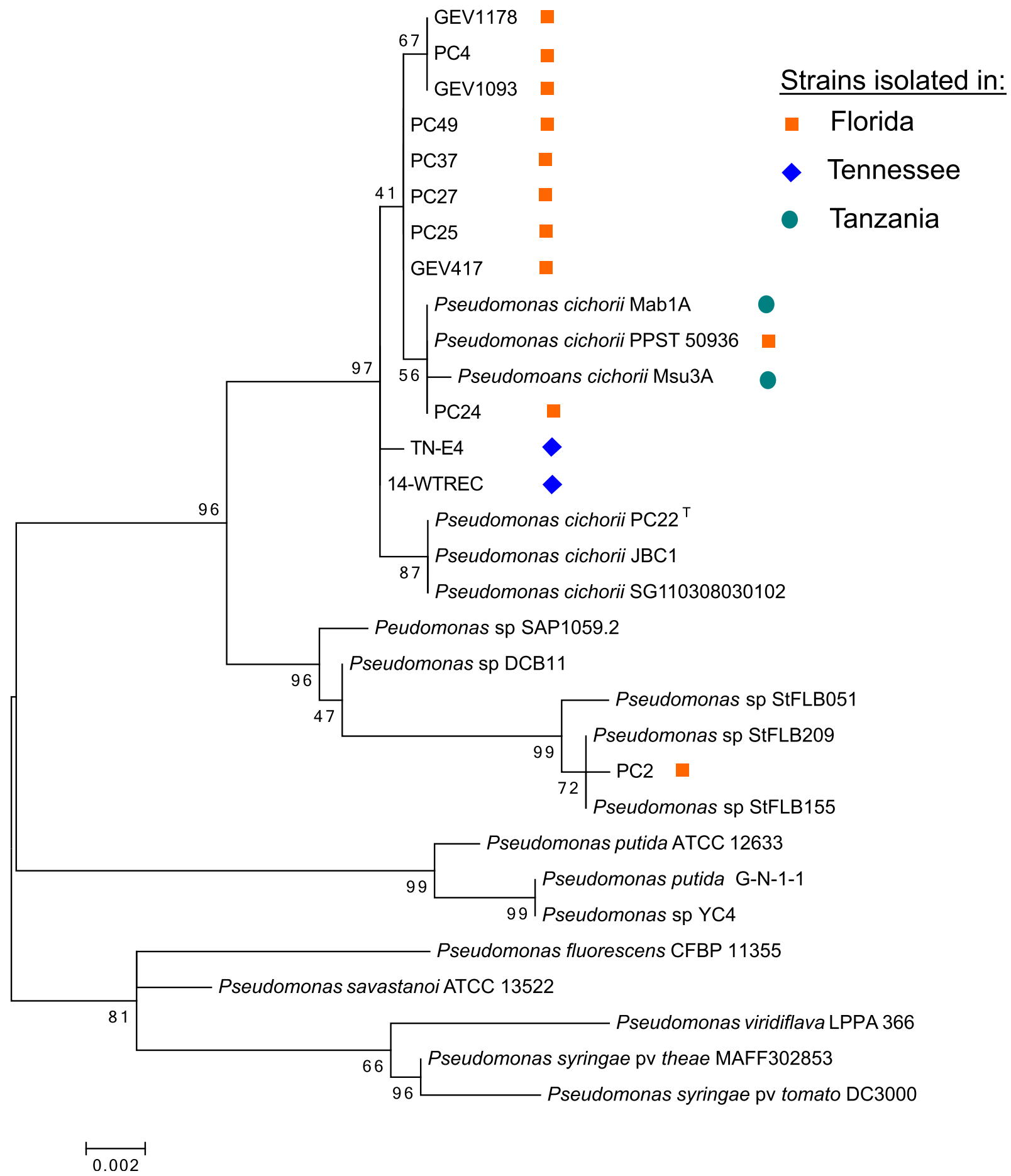

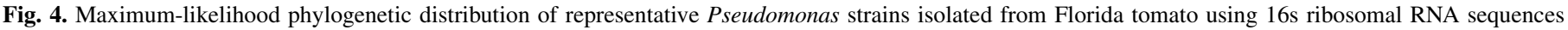
compared with reference sequences. Bootstrap values for each branch are expressed as percentage and scale bar represents substitutions per site. 
had a 16S rRNA sequence identical to the two Florida tomato strains. Florida strains PC25, PC27, PC37, and PC49 isolated in the 1980s and 90s from basil, F. pandurata, F. lyrata, and Euphorbia milii, respectively, had $16 \mathrm{~S}$ sequences identical to the GEV417 strain from tomato. $P$. cichorii strain PC24 isolated from hibiscus had a 16S rRNA sequence identical to $P$. cichorii strain 50936 previously reported from $S$. rebaudiana in Florida and Mab1A (accession KP295477) isolated in Tanzania. The 16S rRNA sequences from two representative strains of $P$. cichorii isolated from pumpkin in Tennessee (14-WTREC and TN-E4) and an additional strain isolated from tomato in Tanzania (Msu3A) were available in NCBI (accessions KU174188, KU174189, and KP295476) (Newberry et al. 2016; Testen et al. 2015). Phylogenetic analysis using 16 S rRNA sequences clustered these strains together but distinct from the type strain (Fig. 4).

Phylogenetic analysis of the cts gene produced similar phylogenetic groupings of the $P$. cichorii strains isolated from Florida. Interestingly, $P$. cichorii strain 83-1, isolated in Arizona from an unknown plant host (Cottyn et al. 2010), had a cts sequence identical to tomato strain GEV1151, isolated in Florida (Supplementary Fig. S3). Genetic distance calculated among $c t s$ sequences showed significant differences among the strains (Supplementary Table S1). Strains isolated from Florida along with $P$. cichorii 83-1 and IBSBF 1274 had a genetic distance of 0 to $2 \%$ and varied from the type strain $\mathrm{PC} 22^{\mathrm{T}}$ by 4.5 to $5.6 \%$. Additionally, $\mathrm{PC} 2$ strain isolated from geranium was genetically different from other $P$. cichorii strains by more than $10 \%$ based on the cts gene sequence only but was identical to Pseudomonas sp. strain StFLB209.

\section{DISCUSSION}

The bacterial strains isolated from symptomatic tomato in Florida were confirmed as $P$. cichorii based on standard LOPAT assay and phylogenetic analyses of housekeeping genes and 16S rRNA sequences. Three different morphotypes and a distinct genomovar pathogenic on tomato are reported within $P$. cichorii (Cottyn et al. 2009; Trantas et al. 2013). However, our study indicates that the P. cichorii strains from Florida along with the strains isolated from tomato in Tanzania form a genetic subgroup distinct from the type strain and other reported $P$. cichorii strains. Phylogenetic analyses using housekeeping genes provided substantial evidence that the population in Florida represents a distinct phylogroup of $P$. cichorii.

The tomato $P$. cichorii strains form a distinct cluster based on MLSA and 16S rRNA sequences. Two allele types of the 16S rRNA sequence were detected among tomato strains. One allele was identical to the $16 \mathrm{~S}$ rRNA of chrysanthemum strain PC4, while only tomato strain GEV417 carried the second 16S rRNA allele type. Interestingly, this second $16 \mathrm{~S}$ rRNA allele type was detected in other $P$. cichorii strains isolated from hosts such as basil, crown of thorns, hibiscus, and two Ficus spp. Both 16S rRNA allele types varied from the type strain (Table 1). Additionally, P. cichorii strain PC2 isolated from geranium was similar to a distant group of Pseudomonas spp. isolated from the potato phyllosphere based on 16S rRNA sequences.

Similar results were also observed with the housekeeping gene sequences. Based on housekeeping gene sequences, two haplotypes were observed among the tomato-pathogenic strains of $P$. cichorii. The strain GEV417 was isolated in 2011 and other tomato strains were isolated in 2012. Because these strains were isolated in different years, the sequence variation between these strains suggests that there were multiple shifts by $P$. cichorii to tomato in Florida. In addition to the Florida strains, representative strains of $P$. cichorii isolated from pumpkin in Tennessee and tomato in Tanzania also clustered with the Florida strains based on $16 \mathrm{~S}$ rRNA and the housekeeping genes gyrB and $r p o D$.

The P. cichorii strains isolated in Florida clustered together in the same phylogenetic group, except for the PC2 strain isolated from geranium. Based on sequence comparisons using 16S rRNA and four housekeeping genes, PC2 was found to be similar to Pseudomonas sp. StFLB209, isolated from potato in Japan. Whole- genome sequence analysis showed that strain StFLB209 from potato is closely related to $P$. cichorii strain JBC1 isolated from soybean in Korea (Morohoshi et al. 2014; Someya et al. 2009). The sequence variations within the Florida $P$. cichorii strains may be due to their associations with different hosts.

Based on the currently established phylogroup definition for the $P$. syringae complex, $P$. cichorii is grouped as phylogroup 11 (Berge et al. 2014). The study described $P$. cichorii phylogroups based on cts gene sequence but included only three representative $P$. cichorii strains and did not include the type strain. In this study, we focused on P. cichorii strains isolated from various hosts in Florida along with the type strain. The results from phylogenetic and genetic distance analysis confirmed the possibility of three independent phylogroups within $P$. cichorii based on current standards. One phylogroup would encompass two strains, including the type strain PC22 $2^{\mathrm{T}}$ and CFBP 4407, isolated from lettuce. The second phylogroup would encompass $P$. cichorii strains isolated from Florida, except PC2, along with $P$. cichorii 83-1 isolated in Arizona. Meanwhile, PC2 along with Pseudomonas sp. strain StFLB209 could represent a potential third phylogroup of $P$. cichorii. The results further indicate the strong possibility that the $P$. cichorii strains present in Florida represent a new phylogroup.

The strains of $P$. cichorii isolated over the last 30 years in Florida clustered together in the same group. Thus, it seems that the $P$. cichorii strains recently isolated from tomato in Florida are representatives of $P$. cichorii already present in Florida that are pathogenic on tomato under favorable environmental conditions and host availability. Although strains of $P$. cichorii have been reported from various hosts in Florida since the early 1980s (Chase 1986), they were not genetically characterized until recently. P. cichorii was previously reported to cause pith necrosis disease of tomato in Greece, New Zealand, and Turkey (Mirik et al. 2011; Trantas et al. 2013; Wilkie and Dye 1974) but sequence information for these strains is not available.

In Florida, $P$. cichorii caused foliar symptoms on tomato, whereas a wide range of symptoms varying from pith necrosis to leaf blight have previously been reported for $P$. cichorii infection in tomato (Testen et al. 2015; Wilkie and Dye 1974). Angular lesions with distinct yellow margins were observed during $P$. cichorii infections in tomato. Pathogenicity results show that $P$. cichorii strains isolated from Florida were pathogenic on more than one host. The $P$. cichorii strains isolated from tomato in Florida were pathogenic on lettuce. Likewise, $P$. cichorii strains isolated from various hosts in Florida and the type strain $\mathrm{PC} 22^{\mathrm{T}}$ were also pathogenic on tomato. The ability of $P$. cichorii to cause disease on multiple hosts suggests that the pathogen can spread to other economically important hosts.

These strains span collections from the early 1980s until 2012. With the exception of PC2, Florida $P$. cichorii strains are phylogenetically similar and their ability to cross-infect hosts suggests that the same phylogenetic group of $P$. cichorii has been affecting multiple hosts within Florida for over 30 years. In addition to Florida, this distinct phylogenetic population of $P$. cichorii encompasses strains from Tennessee and Tanzania. The similarities suggest that phylogenetically similar $P$. cichorii strains could be widespread in various hosts and environmental niches but further identification and characterization using additional representative Pseudomonas strains would be necessary.

The ability of $P$. cichorii strains to infect multiple hosts may cause significant losses to economically important crops in Florida and other areas. In addition to various isolations made in Florida, the reported frequency of diseases caused by $P$. cichorii has increased substantially over the last decade from different geographical locations and from economically important hosts, including tomato (Mirik et al. 2011; Myung et al. 2013; Newberry et al. 2016). Although environmental conditions for $P$. cichorii are favorable in Florida from midspring to early fall, diseases caused by Pseudomonas spp. in tomato are relatively rare compared with the regular outbreaks caused by Xanthomonas spp. during the same period. No 
major disease outbreak linked to Pseudomonas spp. has occurred in tomato in Florida since 2012. However, the pathogen has a wide host range and the increasing spread of $P$. cichorii may pose a potential threat to agricultural industries in Florida. McCarter et al. (1983) reported that Pseudomonas strains could spread through seed and weed hosts. The presence of volunteer hosts in Florida fields may have increased the pathogen's potential to spread to different hosts, including tomato.

In conclusion, a distinct phylogenetic group of $P$. cichorii was observed in Florida and a phylogenetic subgroup specific to tomato was observed among $P$. cichorii strains isolated from Florida. Strains from Tennessee and Tanzania were similar to the P. cichorii phylogenetic group from Florida. Considering the genetic variations within Florida strains, the $P$. cichorii strains already present in various hosts in Florida may have transferred to tomato multiple times. The presence of tomato fields in close proximity to other natural hosts of $P$. cichorii and favorable environmental conditions in Florida may lead to isolated outbreaks. Conducive weather conditions and the presence of multiple hosts throughout the year in Florida are ideal for disease development and the survival of this pathogen.

\section{LITERATURE CITED}

Aysan, Y., Sahin, S., Ulke, G., and Sahin, F. 2003. Bacterial rot of lettuce caused by Pseudomonas cichorii in Turkey. Plant Pathol. 52:782.

Berge, O., Monteil, C. L., Bartoli, C., Chandeysson, C., Guilbaud, C., Sands, D. C., and Morris, C. E. 2014. A user's guide to a database of the diversity of Pseudomonas syringae and its application to classifying strains in this phylogenetic complex. PLoS One 9:e105547.

Burkholder, W. H. 1954. Bacteria pathogenic on head lettuce in New-York state. Phytopathology 44:592-596.

Chase, A. R. 1986. Comparisons of three bacterial leaf spots of Hibiscus rosasinensis. Plant Dis. 70:334-336.

Cottyn, B., Baeyen, S., Pauwelyn, E., Verbaendert, I., De Vos, P., Bleyaert, P., Höfte, M., and Maes, M. 2010. Development of real-time PCR assay for Pseudomonas cichorii, the causal agent of midrib rot in greenhouse-grown lettuce, and its detection in irrigating water. Plant Pathol. 60:453-461.

Cottyn, B., Heylen, K., Heyrman, J., Vanhouteghem, K., Pauwelyn, E., Bleyaert, P., Baerenbergh, J. V., Höfte, M., De Vos, P., and Maes, M. 2009. Pseudomonas cichorii as the causal agent of midrib rot, an emerging disease of greenhouse-grown butterhead lettuce in Flanders. Syst. Appl. Microbiol. $32: 211-225$.

Edgar, R. C. 2004. MUSCLE. Multiple sequence alignment with high accuracy and high throughput. Nucleic Acids Res. 32:1792-1797.

Engelhard, A. W., Mellinger, H. C., Ploetz, R. C., and Miller, J. W. 1983. A leaf spot of florists' geranium incited by Pseudomonas cichorii. Plant Dis. 67:541-544.

Gumtow, R. L., Khan, A. A., Bocsanczy, A. M., Yuen, J. M., Palmateer, A. J., and Norman, D. J. 2013. First report of a leaf spot disease of golden dewdrop (Duranta erecta) caused by Pseudomonas cichorii and a Xanthomonas species in Florida. Plant Dis. 97:836.

Hwang, M. S., Morgan, R. L., Sarkar, S. F., Wang, P. W., and Guttman, D. S. 2005. Phylogenetic characterization of virulence and resistance phenotypes of Pseudomonas syringae. Appl. Environ. Microbiol. 71:5182-5191.

Jones, J. B., Engelhard, A. W., and Raju, B. C. 1983a. Outbreak of a stem necrosis on chrysanthemum incited by Pseudomonas cichorii in Florida. Plant Dis. 67:431-433.

Jones, J. B., Jones, J. P., McCarter, S. M., and Stall, R. E. 1984. Pseudomonas viridiflava: Causal agent of bacterial leaf blight of tomato. Plant Dis. 68:341-342.

Jones, J. B., Jones, J. P., Stall, R. E., and Miller, J. W. 1983b. Occurrence of stem necrosis on field-grown tomatoes incited by Pseudomonas corrugata in Florida. Plant Dis. 67:425-426.

Jones, J. B., Randhawa, P. S., and Sasser, M. 1990. Selective isolation of Pseudomonas cichorii from soil and from leaves and buds of Dendranthema grandiflora. Plant Dis. 74:300-303.

King, E. O., Ward, M. K., and Raney, D. E. 1954. Two simple media for the demonstration of pyocyanin and fluorescin. J. Lab. Clin. Med. 44:301-307.

LeBoeuf, J., Cuppels, D., Dick, J., Pitblado, R., Loewen, S., and Celetti, M. 2005. Bacterial diseases of tomato: Bacterial spot, bacterial speck, bacterial canker. Online publication. Ontario Ministry of Agriculture, Food and Rural Affairs. http://www.omafra.gov.on.ca/english/crops/facts/05-069.htm

Lelliott, R. A., Billing, E., and Hayward, A. C. 1966. A determinative scheme for the fluorescent plant pathogenic pseudomonads. J. Appl. Bacteriol. 29: 470-489.
Marchesi, J. R., Sato, T., Weightman, A. J., Martin, T. A., Fry, J. C., Hiom, S. J., and Wade, W. G. 1998. Design and evaluation of useful bacteriumspecific PCR primers that amplify genes coding for bacterial 16S rRNA. Appl. Environ. Microbiol. 64:795-799.

McCarter, S. M., Jones, J. B., Gitaitis, R. D., and Smitley, D. R. 1983. Survival of Pseudomonas syringae pv. tomato in association with tomato seeds, soil, host tissue, and epiphytic weed hosts in Georgia. Phytopathology 73: 1393-1398.

Mirik, M., Aysan, Y., and Sahin, F. 2011. Characterization of Pseudomonas cichorii isolated from different hosts in Turkey. Int. J. Agric. Biol. 13: 203-209.

Morohoshi, T., Kato, T., Someya, N., and Ikeda, T. 2014. Complete genome sequence of $\mathrm{N}$-acylhomoserine lactone-producing Pseudomonas sp. strain StFLB209, isolated from potato phyllosphere. Genome Announc. 2: e01037-14.

Morris, C. E., Sands, D. C., Vanneste, J. L., Montarry, J., Oakley, B., Guilbaud, C., and Glaux, C. 2010. Inferring the evolutionary history of the plant pathogen Pseudomonas syringae from its biogeography in headwaters of rivers in North America, Europe, and New Zealand. MBio 1:e00107-10.

Mulet, M., Lalucat, J., and Garcia-Valdés, E. 2010. DNA sequence-based analysis of the Pseudomonas species. Environ. Microbiol. 12:1513-1530.

Myung, I.-S., Choi, J.-K., Lee, J. Y., Yoon, M. J., Hwang, E. Y., and Shim, H. S. 2013. First report of bacterial leaf spot of witloof, caused by Pseudomonas cichorii in Korea. Plant Dis. 97:1376.

Newberry, E. A., Paret, M. L., Jones, J. B., and Bost, S. C. 2016. First report of leaf spot of pumpkin caused by Pseudomonas cichorii in Tennessee. Plant Dis. 100:2159

Pohronezny, K., Sommerfeld, M. L., and Raid, R. N. 1994. Streptomycin resistance and copper tolerance among strains of Pseudomonas cichorii in celery seedbeds. Plant Dis. 78:150-153.

Ramkumar, G., Lee, S. W., Weon, H.-Y, Kim, B.-Y., and Lee, Y. H. 2015. First report on the whole genome sequence of Pseudomonas cichorii strain JBC1 and comparison with other Pseudomonas species. Plant Pathol. 64:63-70.

Sarkar, S. F., and Guttman, D. S. 2004. Evolution of the core genome of Pseudomonas syringae, a highly clonal, endemic plant pathogen. Appl. Environ. Microbiol. 70:1999-2012.

Scortichini, M., Marchesi, U., Rossi, M. P., and Di Prospero, P. 2002. Bacteria associated with hazelnut (Corylus avellana L.) decline are of two groups: Pseudomonas avellanae and strains resembling $P$. syringae pv. syringae. Appl. Environ. Microbiol. 68:476-484.

Someya, N., Morohoshi, T., Okano, N., Otsu, E., Usuki, K., Sayama, M., Sekiguchi, H., Ikeda, T., and Ishida, S. 2009. Distribution of N-Acylhomoserine Lactone-producing fluorescent Pseudomonas in the phyllosphere and rhizosphere of Potato (Solanum tuberosum L.). Microbes Environ. 24: 305-314.

Stead, D. E., Simpkins, S. A., Weller, S. A., Hennessy, J., Aspin, A., Stanford, H., Smith, N. C., and Elphinstone, J. G. 2003. Classification and identification of plant pathogenic Pseudomonas species by REP-PCR derived genetic fingerprints. Pages 411-420 in: Pseudomonas syringae and Related Pathogens. N. S. Iacobellis, A. Collmer, S. W. Hutcheson, J. W. Mansfield, C. E. Morris, J. Murillo, N. W. Schaad, D. E. Stead, G. Surico, and M. S. Ullrich, eds. Springer, Netherlands.

Strayer, A., Garcia-Maruniak, A., Sun, X., Schubert, T., and Sutton, B. 2012. First report of Pseudomonas cichorii causing leaf spot of stevia detected in Florida. Plant Dis. 96:1690.

Swingle, D. B. 1925. Center rot of French endive or wilt of chicory (Cichorium intybus $\mathrm{L}$.). Phytopathology 15:730.

Tamura, K., Stecher, G., Peterson, D., Filipski, A., and Kumar, S. 2013. MEGA6: Molecular evolutionary genetics analysis version 6.0. Mol. Biol. Evol. 30:2725-2729.

Testen, A. L., Nahson, J., Mamiro, D. P., and Miller, S. A. 2015. First report of tomato pith necrosis caused by Pseudomonas cichorii in Tanzania. Plant Dis. 99:1035.

Trantas, E. A., Sarris, P. F., Mpalantinaki, E. E., Pentari, M. G., Ververidis, F. N., and Goumas, D. E. 2013. A new genomovar of Pseudomonas cichorii, a causal agent of tomato pith necrosis. Eur. J. Plant Pathol. 137: 477-493.

Vallad, G. E., Pernezny, K., and Momol, T. 2009. A series of diseases in the Florida vegetable garden: Tomato (revised). Plant Pathology Department, University of Florida/Institute of Food and Agricultural Science Extension PP200.

Wilkie, J. P., and Dye, D. W. 1974. Pseudomonas cichorii causing tomato and celery diseases in New Zealand. N. Z. J. Agric. Res. 17:123-130.

Yamamoto, S., Kasai, H., Arnold, D. L., Jackson, R. W., Vivian, A., and Harayama, S. 2000. Phylogeny of the genus Pseudomonas: Intrageneric structure reconstructed from the nucleotide sequence of $\mathrm{gyrB}$ and $r p o D$ genes. Microbiology 146:2385-2394. 